\title{
Establishing an operational waterhole monitoring system using satellite data and hydrologic modelling: Application in the pastoral regions of East Africa
}

Gabriel B Senay ${ }^{1,2^{*}}$, Naga Manohar Velpuri ${ }^{3}$, Henok Alemu ${ }^{2}$, Shahriar Md Pervez ${ }^{3}$, Kwabena O Asante ${ }^{4}$, Gatarwa Kariuki ${ }^{5}$, Asefa Taa ${ }^{6}$ and Jay Angerer ${ }^{7}$

\begin{abstract}
Timely information on the availability of water and forage is important for the sustainable development of pastoral regions. The lack of such information increases the dependence of pastoral communities on perennial sources, which often leads to competition and conflicts. The provision of timely information is a challenging task, especially due to the scarcity or non-existence of conventional station-based hydrometeorological networks in the remote pastoral regions. A multi-source water balance modelling approach driven by satellite data was used to operationally monitor daily water level fluctuations across the pastoral regions of northern Kenya and southern Ethiopia. Advanced Spaceborne Thermal Emission and Reflection Radiometer data were used for mapping and estimating the surface area of the waterholes. Satellite-based rainfall, modelled run-off and evapotranspiration data were used to model daily water level fluctuations. Mapping of waterholes was achieved with $97 \%$ accuracy. Validation of modelled water levels with field-installed gauge data demonstrated the ability of the model to capture the seasonal patterns and variations. Validation results indicate that the model explained $60 \%$ of the observed variability in water levels, with an average root-mean-squared error of $22 \%$. Up-to-date information on rainfall, evaporation, scaled water depth and condition of the waterholes is made available daily in near-real time via the Internet (http://watermon.tamu.edu). Such information can be used by non-governmental organizations, governmental organizations and other stakeholders for early warning and decision making. This study demonstrated an integrated approach for establishing an operational waterhole monitoring system using multi-source satellite data and hydrologic modelling.
\end{abstract}

Keywords: Remote sensing; Satellite data; Water monitoring; Pastoral regions; Hydrologic modelling

\section{Introduction}

Arid and semiarid regions cover nearly one third of the global land and are inhabited by around 400 million people. These regions are typically dominated by rangelands characterized by limited rainfall and desiccating weather conditions. In Africa, rangelands occupy a substantial portion of the arid and semiarid land areas and support

\footnotetext{
* Correspondence: senay@usgs.gov

${ }^{1}$ U.S. Geological Survey (USGS) Earth Resources Observation and Science (EROS) Center, 252nd Street, Sioux Falls, SD 47914, USA

${ }^{2}$ GISc Center of Excellence, South Dakota State University, 1021 Medary Avenue, Brookings, SD, USA

Full list of author information is available at the end of the article
}

large human populations who are dependent on grazing livestock. Countries such as Sudan, Somalia, Ethiopia and Kenya have a considerable number of pastoralists. However, scarcity of water and forage combined with limited precipitation and high desiccating factors have exposed the pastoral communities to severe drought conditions. In spite of the harsh conditions, pastoralists have always shown an ability to survive through a variety of adaptations such as rearing a wide variety of livestock, migrating to areas where water and forage are available and even switching to other forms of livelihood during extremely harsh conditions (Fratkin 2001). Pastoral communities mostly rely on traditional methods such as on historical memory, cloud 
behaviour at a given time of the year, and behaviour of plants and animals to develop coping strategies during crisis situations (Stuth et al. 2003). However, the frequency of floods and droughts in the region has greatly increased (Fratkin 2001). As a result, many of the traditional approaches have failed, so more reliable and scientifically proven strategies to cope with adverse weather conditions need to be established.

Gaining access to forage and water is critical for pastoralists (Scoones and Graham 1994). One of the foremost strategies adopted by the pastoral communities to evade adverse conditions is migration. Most of the time, pastoral communities migrate large distances (hundreds of kilometres) in search of forage and water. However, lack of knowledge on where to find available forage and water is a major limiting factor for migration. Generally, pastoralists rely on traditional knowledge on resource availability or employ scouts to locate forage and water. These scouts are specially trained people who venture out to new lands in search of resources.

Due to lack of resources and funding, even nongovernmental organizations (NGOs) and local government agencies working in the pastoral areas rely on the historical knowledge and information gathered from regional surveys for planning and decision making. These methods often result in a congregation of several communities toward more reliable and perennial sources of forage and water, leading to competition and conflicts. However, these traditional methods of gathering information on the availability of resources are time-consuming and unreliable. Furthermore, the scouts are often at risk as they venture into highly volatile cross-border areas. Recently, conflicts among pastoral communities have become more common across the border areas of Sudan, Ethiopia, Kenya and Somalia (Meier et al. 2007; Hagmann and Alemmaya 2008; Hundie 2010).

Out of the two main critical resources (forage and water) required for pastoral development, methods for mapping and monitoring forage conditions in the pastoral regions are available. Remote sensing data have been widely used for mapping and monitoring of forage conditions because they can be used to monitor large areas. Several researchers (Tueller 1989; Booth and Tueller 2003; Hunt et al. 2003; Rango et al. 2009) provided a detailed overview of the applications of remote sensing technology in rangeland management. Remote sensing data are extensively used for mapping and assessing forage conditions and for famine early warning systems in many pastoral regions of the world (Senay and Elliott 2002; Thoma et al. 2002; Reeves et al. 2002; Grigera et al. 2007). There are also models available which integrate satellite data and other weather information to monitor and forecast forage conditions. One such forage production model is PHYGROW, which can simulate forage production and carrying capacity of sub-tropical shrubland grazed by various ratios of cattle and goats (Rowan 1995; Stuth et al. 2003; Jama et al. 2009). This model has been widely used in the Livestock and Early Warning System project funded by Global Livestock Collaborative Research Support Program.

However, a critical missing piece in this model is the component to monitor changes in water availability. The information on the water availability is highly critical for pastoralists as they select forage sites in close proximity to where water is available. However, a quick review of literature suggests that water resources in the pastoral regions have not been monitored because of the remoteness of the area, inaccessibility issues and lack of hydrometeorological networks. The overarching goal of this study was to present an approach which uses cost-free satellitebased products that are readily available online to monitor waterholes fed by surface water in data-scarce pastoral regions. The objective of this research is to provide information in near-real time on the seasonal patterns and daily variations of waterhole water levels so that pastoralists, NGOs and other governmental organizations can use the information for timely decision making and drought early warning purposes.

\section{Background}

\section{Hydrologic model and satellite data}

Using satellite data for water resources monitoring offers great advantages over conventional methods. In this study, we used a water balance approach similar to the lake level modelling approach (Velpuri et al. 2012; Velpuri and Senay 2012). The approach used in this study employs a water balance approach driven by satellite data to derive fluctuations in water levels. The remotely sensed precipitation, modelled run-off and evapotranspiration data are ingested into this spatially distributed model that is parameterized using Shuttle Radar Topography Mission (SRTM) digital elevation data, Tropical Rainfall Measuring Mission (TRMM) rainfall and estimated run-off and evapotranspiration data. The list and characteristics of the data sets used in this study are shown in Table 1. Assuming a rectangular cross section of the waterholes, the changes in depth in a waterhole are expressed as:

$$
\Delta D=P+R_{\text {in }}+G_{\text {in }}-E-R_{\text {out }}-G_{\text {out }}-S
$$

where $\Delta D(\mathrm{~m})$ denotes change in depth of water levels, $P(\mathrm{~m})$ is the precipitation over the waterhole extracted from the TRMM rainfall estimate, $R_{\text {in }}(\mathrm{m})$ is the modelled run-off contribution to the waterhole and $R_{\text {out }}(\mathrm{m})$ is the outflow from the waterhole (occurs when water level exceeds maximum capacity), $G_{\text {in }}(\mathrm{m})$ and $G_{\text {out }}(\mathrm{m})$ are the groundwater inflows and outflows affecting the waterhole, respectively, $E(\mathrm{~m})$ is the evaporation over the waterhole 
Table 1 Satellite data, products and other ancillary data used in this study

\begin{tabular}{llllll}
\hline No. & Data & Satellite sensor/source & Frequency & Resolution/scale & Reference \\
\hline 1 & Satellite rainfall estimate & TRMM 3B42 & Daily & $0.25^{\circ} \times 0.25^{\circ}$ & Huffman 1997 \\
2 & Global GDAS reference ET & Model-assimilated satellite data & Daily & $0.1^{\circ} \times 0.1^{\circ}$ & Senay et al. 2008 \\
3 & ASTER & VNIR and SWIR & Multiple dates & $15 \mathrm{~m}$ & - \\
4 & Digital elevation model & SRTM V 4.0 & Single date & $90 \mathrm{~m}$ & Farr et al. 2000 \\
5 & Run-off coefficient data for Africa & SCS curve number method & Single date & $10 \mathrm{~km}$ & Senay and Verdin 2004 \\
6 & Waterhole water level data & Field data collection & 2008 to 2010 & - & This study \\
\hline
\end{tabular}

extracted from Global Data Assimilation System (GDAS) reference evapotranspiration (ETo), and $S(\mathrm{~m})$ denotes seepage losses from the waterhole.

Rainfall estimates from the TRMM 3 B42 merged high-quality infrared precipitation product (Huffman 1997) are available from the National Aeronautics and Space Administration (NASA) website. However, some end users do not have the means to manipulate such data into readily usable formats. Hence, the U.S. Geological Survey (USGS) Earth Resources Observation and Science (EROS) Center distributes processed data (gridded daily rainfall data in readily usable geographic information system (GIS) formats) through an anonymous FTP site. The rainfall estimates are available since December 1997 at $0.25^{\circ} \times 0.25^{\circ}$ grid resolution. Several researchers have validated TRMM rainfall estimates with rain gauge data (Nicholson et al. 2003a, 2003b; Ji 2006; Hazarika et al. 2007; Harris et al. 2007) over different parts of the world and found that TRMM rainfall estimates reasonably capture the trends in rainfall patterns. Furthermore, Dinku et al. (2008) extensively evaluated TRMM 3B42 rainfall estimates using rain gauge data from Ethiopia and found that satellite estimates compare reasonably well with rain gauge data with an overall correlation coefficient of 0.72 . Satellitebased rainfall estimates are used to estimate the surface run-off contribution to each waterhole $\left(R_{\text {in }}\right)$ and to quantify direct rain $(P)$ over the waterhole.

Daily Reference daily evapotranspiration (ETo) data are produced using 6-hourly meteorological data from the National Oceanic and Atmospheric Administration GDAS using the standardized Penman-Monteith equation (Senay et al. 2008). The ETo data are available with a $1^{\circ} \times 1^{\circ}$ spatial resolution from the USGS EROS website. The GDAS ETo was validated elsewhere by Senay et al. (2008), and it was found to have a high correlation coefficient of 0.99 with the ETo derived from observations made at weather stations and thus demonstrated the usability of GDAS ETo in large-scale hydrologic modelling studies and early warning applications. GDAS ETo is the sum of evaporation from the soil surface and transpiration from a standardized reference clipped grass surface fully covering the ground (Allen et al. 1998). However, evaporation from open water bodies $(E)$ in small waterholes and shallow ponds is generally slightly higher than the reference ETo and hence can be represented by an evapotranspiration fraction value of 1.05 (Allen et al. 1998).

Other parameters such as groundwater fluxes and surface outflows $\left(G_{\text {in }}, G_{\text {out }}, R_{\text {out }}\right.$ and $S$ ) remain unknowns as in most water budget studies. In most regions, information on groundwater fluxes and surface outflows are not available because gauging networks are absent. Furthermore, $G_{\text {in }}$ and $G_{\text {out }}$ can be assumed to be identical for small water bodies. Most of the waterholes in this study are closed (do not have an outlet). However, $R_{\text {out }}$ can happen when water level exceeds the capacity of the waterhole. Similarly, $S$ was estimated based on the information on soils.

The location and surface area of the waterholes were delineated using Advanced Spaceborne Thermal Emission and Reflection Radiometer (ASTER) 15-m data. A digital elevation model derived from the SRTM data was used to derive several hydrological derivatives such as streams, river networks and catchment areas for each waterhole identified from ASTER data. The SRTM 90-m spatial resolution data are freely available online in readily usable GIS format. A flow chart illustrating the integration of multi-source satellite data into a water balance model is shown in Figure 1.

\section{Material and methods Study area}

The study area extends from southern Ethiopia to northern Kenya (Figure 2) and covers nearly $150,000 \mathrm{~km}^{2}$. It includes the Moyale, Yabello, Filtu and Arero districts in southern Ethiopia and the Marsabit, Moyale, Wajir and Mandera districts in northern Kenya. The dominant pastoral (ethnic) groups inhabiting the region are the Borana and Somali. The Borana are predominant in the central portion of the study area, extending from Yabello in Ethiopia southward into Isiolo district of Kenya. The Somali pastoralist communities occupy the majority of the eastern portion of the study area, extending eastward into Somalia and northeastern Ethiopia. Additionally, several other smaller groups inhabit the study area.

The area is characterized as arid to semiarid, with harsh weather conditions - low rainfall and high desiccating factors for most of the year. The soils are 


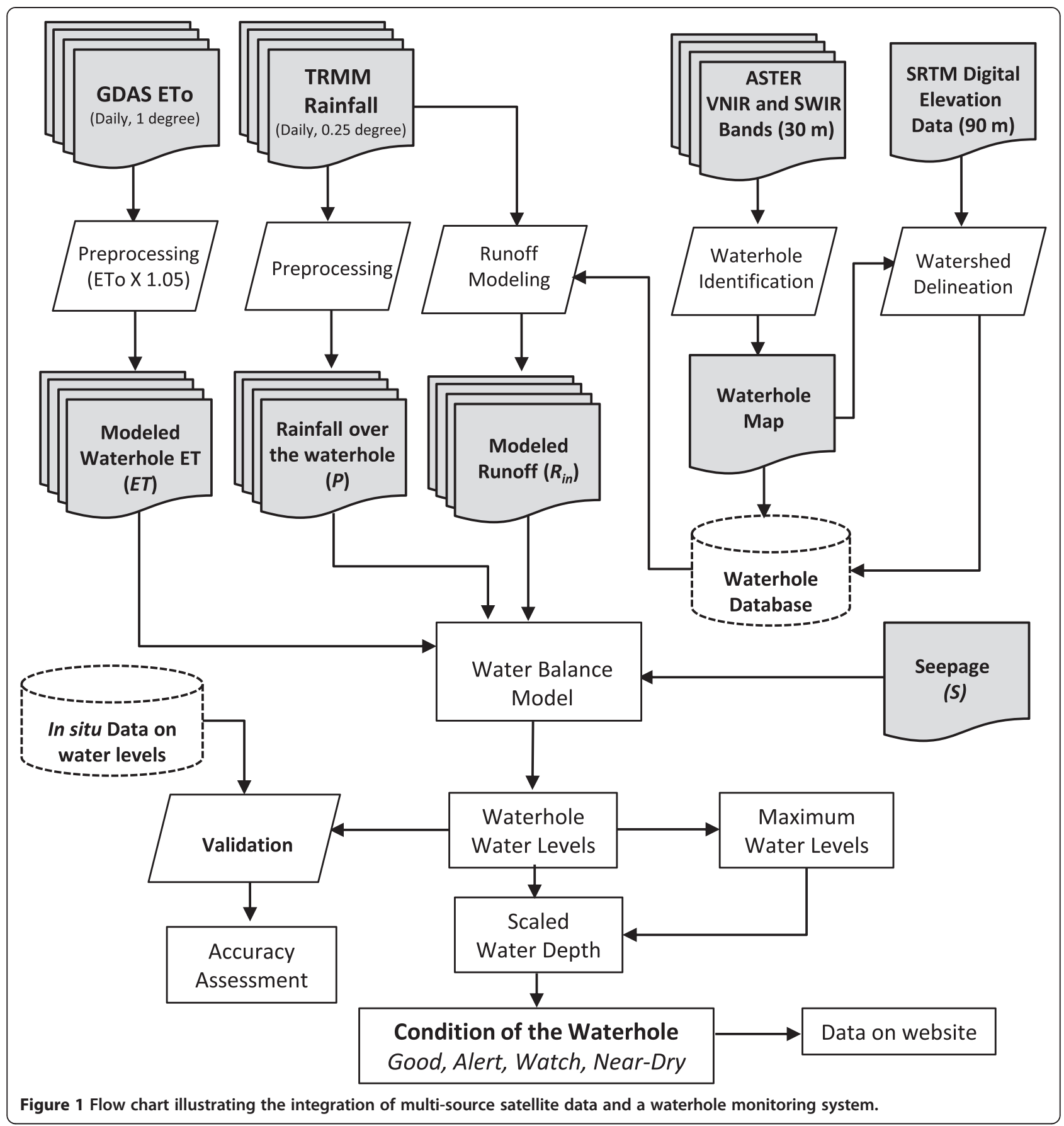

predominantly strongly weathered acid soils (Ferralsols or Acrisols) with low fertility (Sombroek et al. 1982). The rainfall pattern is bimodal in the region, with short rains occurring between October and December and the long rains occurring between March and May followed by a long dry season. Annual rainfall distribution ranges from 300 to $800 \mathrm{~mm}$ with a study-site average of around $450 \mathrm{~mm}$. Water resources available to pastoralists in the study area include natural ponds and springs, man-made pans, shallow hand-dug wells and a few boreholes. A large proportion of these surface water resources hold water only during rainy seasons and remain dry for the rest of the year. This study area was chosen because of its arid climate, limited water availability and high dependence of livestock production on erratic surface water resources in the region. It is also an area characterized by growing conflicts between communities over land, water and pasture availability. 


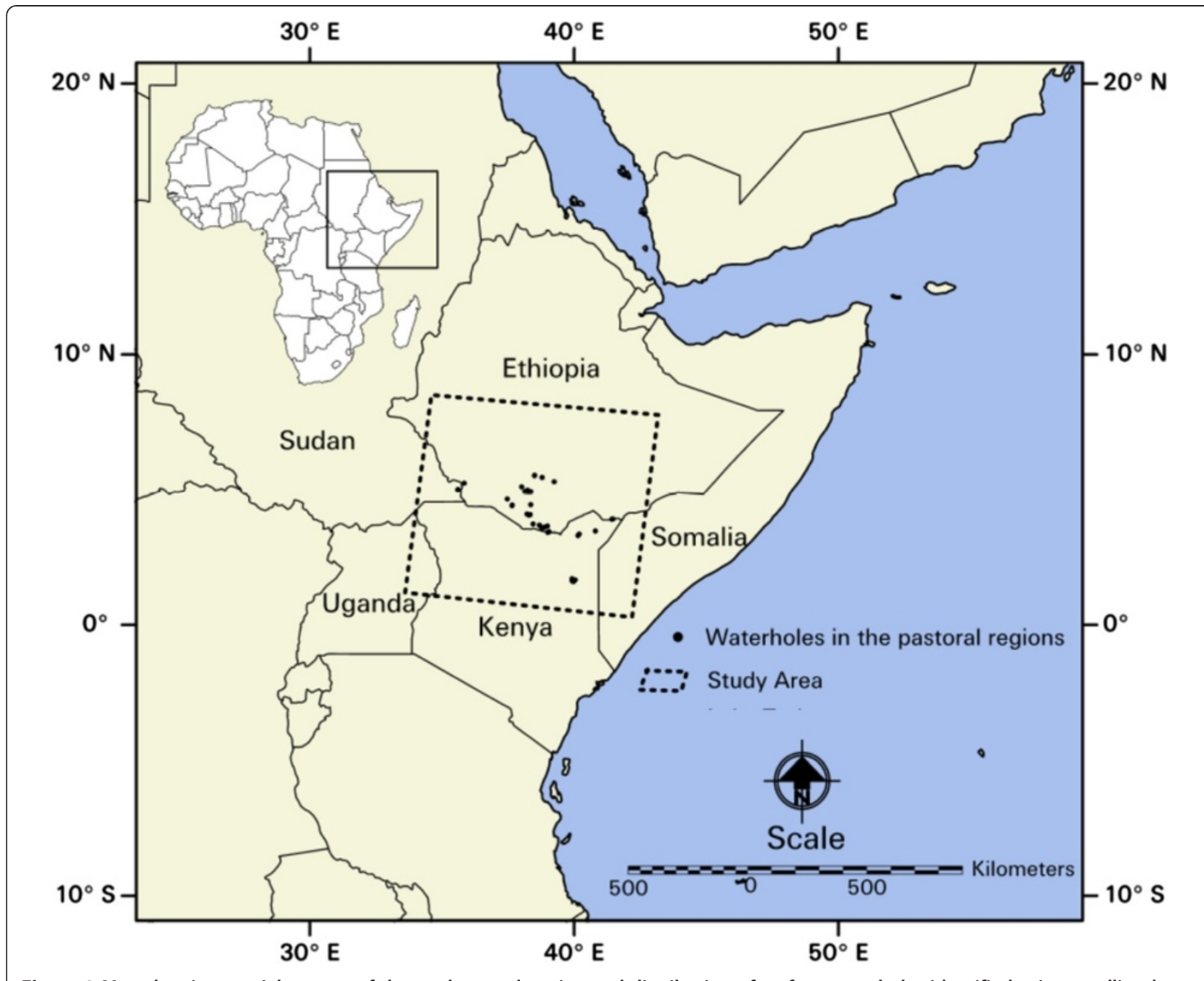

Figure 2 Map showing spatial extents of the study area, location and distribution of surface waterholes identified using satellite data.

\section{Identification of waterholes using ASTER imagery}

This study focuses on surface water bodies that are visible from the ASTER imagery. In this study, 70 ASTER images were used to identify waterholes. To delineate the maximum number of waterholes, images with less than $10 \%$ cloud cover were used and dry season images were excluded. Table 2 shows the temporal distribution of ASTER imagery used in this study. Clouds and cloud shadows were first masked out, and visible and nearinfrared (VNIR) and short-wave infrared (SWIR) bands were used for the identification of natural and man-made water bodies.

To delineate surface water bodies from the ASTER imagery, different approaches were adopted to map two kinds of waterholes: (a) clear-water and (b) water-like waterholes. A simple band ratio (SBR) of near-infrared and red was applied to map clear-water waterholes as shown in Equation 1. An SBR value less than or equal to 1.0 was used
Table 2 Temporal distribution of ASTER imagery used in this study

$\begin{array}{llllllll}2000 & 2001 & 2002 & 2003 & 2004 & 2005 & 2006 & \text { Total }\end{array}$

\begin{tabular}{lcccccccc}
\hline January & - & - & - & - & - & - & - & - \\
February & - & - & - & - & - & - & - & - \\
March & - & - & - & - & - & - & - & - \\
April & - & - & - & 2 & - & - & - & 2 \\
May & - & - & - & - & - & - & - & - \\
June & - & - & - & - & - & - & 1 & 1 \\
July & - & - & - & - & - & 1 & 2 & 3 \\
August & 3 & 2 & - & 3 & 5 & 4 & - & 17 \\
September & - & - & - & 3 & 3 & 3 & - & 9 \\
October & - & - & - & - & - & 2 & 1 & 3 \\
November & - & 2 & - & 1 & - & 2 & - & 5 \\
December & 16 & 4 & - & - & - & 8 & 2 & 30 \\
Total & 19 & 8 & 0 & 9 & 8 & 20 & 6 & 70
\end{tabular}


to extract clear-water waterholes, whereas a value more than 1.0 would be considered a non-water feature:

$$
S B R=\frac{\text { ASTER_Band } 3_{\text {B }}}{\text { ASTER_Band } 2}
$$

where Band 3 and Band 2 are near-infrared (NIR) and red bands from the ASTER data. This approach is highly beneficial to classify water bodies which are clear or deep as they show distinct spectral differences with other land cover types. This is due to the well-known behaviour of water in absorbing NIR radiation longer than the red.

To identify and classify waterholes that were shallow or with poor water quality, the mean absolute deviation (MAD) was estimated using all the VNIR and SWIR bands, and a dynamic threshold was used to identify water-like features. The threshold varied depending on the date of image acquisition and geographic location. The mean absolute deviation is given in Equation 3:

$$
M A D=\frac{1}{N} \sum_{j=1}^{N}\left|x_{j}-\bar{x}\right|
$$

where $x_{j}$ represents the ASTER band reflectance value, $\bar{x}$ denotes average value for all bands for a pixel and $N$ is the total number of bands used.

\section{Characterization of waterholes}

A field campaign was carried out in August 2007 to verify the location of the waterholes using hand-held global positioning system (GPS) units and to characterize the general hydrology of the waterholes identified using ASTER imagery. The objective of the field campaign was to validate the location of the waterholes and to identify the waterholes that are (a) groundwater fed, (b) saline, (c) not being used by the pastoralists or currently being used only by wildlife and (d) inaccessible or unsafe for livestock; such waterholes were eliminated from further analysis and modelling. Information on other characteristics of waterholes such as the type of waterholes (natural ponds, pans, dams, earthen dams) and the usability of waterholes was gathered and recorded.

\section{Run-off modeling}

The study area is very dry with sparse vegetation, and most of the rainfall either infiltrates or is lost due to evaporation, which is common in arid and semiarid regions (Xu and Singh 2004). A very small portion of the rainfall over the catchment is converted to surface run-off and finally reaches the water bodies. In this study, surface run-off was estimated from the SCS curve number procedure (SCS 1972). Senay and Verdin (2004) generated gridded annual run-off estimates for Africa at 10-km spatial resolution. The annual run-off coefficients were summarized for the study area and were found to vary from 0.02 to 0.1 with an average coefficient of 0.05 . We used the average run-off coefficient in combination with TRMM rainfall to estimate catchment run-off contribution. The use of a uniform run-off coefficient makes the modelling approach simple and parsimonious, but less accurate. However, considering the homogeneous and dry landscape and since the objective of this study was to model the patterns and variations in the waterhole water levels and not the absolute water levels, the use of a constant run-off coefficient produces run-off estimates with a reliable precision.

To estimate run-off contribution for each waterhole, the waterholes identified from the ASTER imagery were rasterized into $30-\mathrm{m}$ grid cells. These grid cells corresponding to the waterholes were used as discharge points, and catchment areas for each waterhole were delineated from the SRTM digital elevation data resampled to $30 \mathrm{~m}$. Then, run-off contribution, $R_{\text {in }}(\mathrm{m})$, to each waterhole was estimated using Equation 4:

$$
R_{i n}=\frac{\alpha \times P \times A_{w s}}{A_{w h}}
$$

where $\alpha$ (unitless) represents the rainfall-run-off coefficient for each waterhole $(\alpha=0.05), P$ is the spatial mean TRMM rainfall received over the contributing area (watershed of the waterhole), $A_{\mathrm{ws}}\left(\mathrm{m}^{2}\right)$ is the surface area of the watershed and $A_{\mathrm{wh}}\left(\mathrm{m}^{2}\right)$ is the surface area of the waterhole.

\section{Modelling waterhole water depths}

Using rainfall, estimated run-off and evapotranspiration data for each catchment, a daily water balance was conducted to model waterhole water levels. Furthermore, waterholes that are fed by groundwater systems and waterholes with natural outlets were excluded, and only waterholes fed by surface water were considered in this study. Hence, Equation 1 was further simplified as shown below:

$$
\Delta D=P+R_{\text {in }}-E-S
$$

A constant seepage $(S)$ value of $0.002 \mathrm{~m}$ per day was used considering the soil information obtained from Sombroek et al. (1982). Once the change in water level for each day was estimated, the water level for each waterhole was estimated daily as:

$$
\omega_{i}=\omega_{i-1}+\Delta D_{i}
$$

where $\omega$ is the water level in the waterhole and subscripts $i$ and $i-1$ denote the current and the previous time step, respectively. Water level was set to zero when $\omega$ was found to be negative.

Because the objective of this paper was to present an approach to monitor the patterns and variations in waterholes rather than the absolute levels, modelled water level data 
for each waterhole were converted to scaled depth $\left(\omega_{s}\right)$ from 0 to 100, where 0 denotes minimum depth and 100 denotes the maximum depth of the waterhole:

$$
\omega_{s}=\frac{\omega_{i}}{\omega_{\max }} \times 100
$$

where $\omega_{i}$ represents the current depth and $\omega_{\max }$ is the maximum depth value for each waterhole which was obtained from the modelled water levels over 1998 to 2011. The $\omega_{\max }$ values ranged from 1 to $3 \mathrm{~m}$.

Procedures and codes for the operational module were written to (a) download the rainfall and ET data from the Internet on a daily basis, (b) process and run the water balance module for each waterhole, (c) update the water levels for the waterholes under study and (d) update the website with the waterhole water level information in near-real time, with a one-day delay.

\section{Climate association}

The study area experienced El Niño events in 1998 (Anyamba et al. 2001; Galvin et al. 2001; Behera et al. 2005) and in 2006 to 2007 (IFRC 2006), and severe droughts in 2000 (WFP 2000) and 2009. The responses of the waterholes to these climatic variations were tested. A waterhole was said to respond to a drought when the water level always remained below $33 \%$ capacity during the entire drought season. During heavy rains or an El Niño event, the waterhole was said to be responsive if the water level reaches more than $66 \%$ capacity during the rainfall season. Based on these thresholds, responses of each waterhole were identified.

\section{Validation of waterhole water level fluctuations}

Waterholes in the pastoral regions are unmonitored and ungauged. In order to perform validation of the modelled waterhole, in situ observations of the water levels were needed. However, it was not possible to monitor all the waterholes selected for operational modelling and monitoring. Due to accessibility and other logistics, only a few waterholes were selected for collecting in situ data. Staff gauges were installed in these waterholes in cooperation with the International Livestock Research Institute in Kenya and Oromiya Agricultural Research Institute in Ethiopia.

As part of this exercise, eight waterholes in Kenya and seven in Ethiopia were chosen and gauges were installed during August 2008. However, monitoring efforts at five waterholes in Kenya and two in Ethiopia were abandoned as these gauges were removed or vandalized, leaving only three waterholes in Kenya and five in Ethiopia for in situ monitoring. Data on the water levels from these waterholes were collected on a weekly to monthly basis. Figure 3 shows gauge

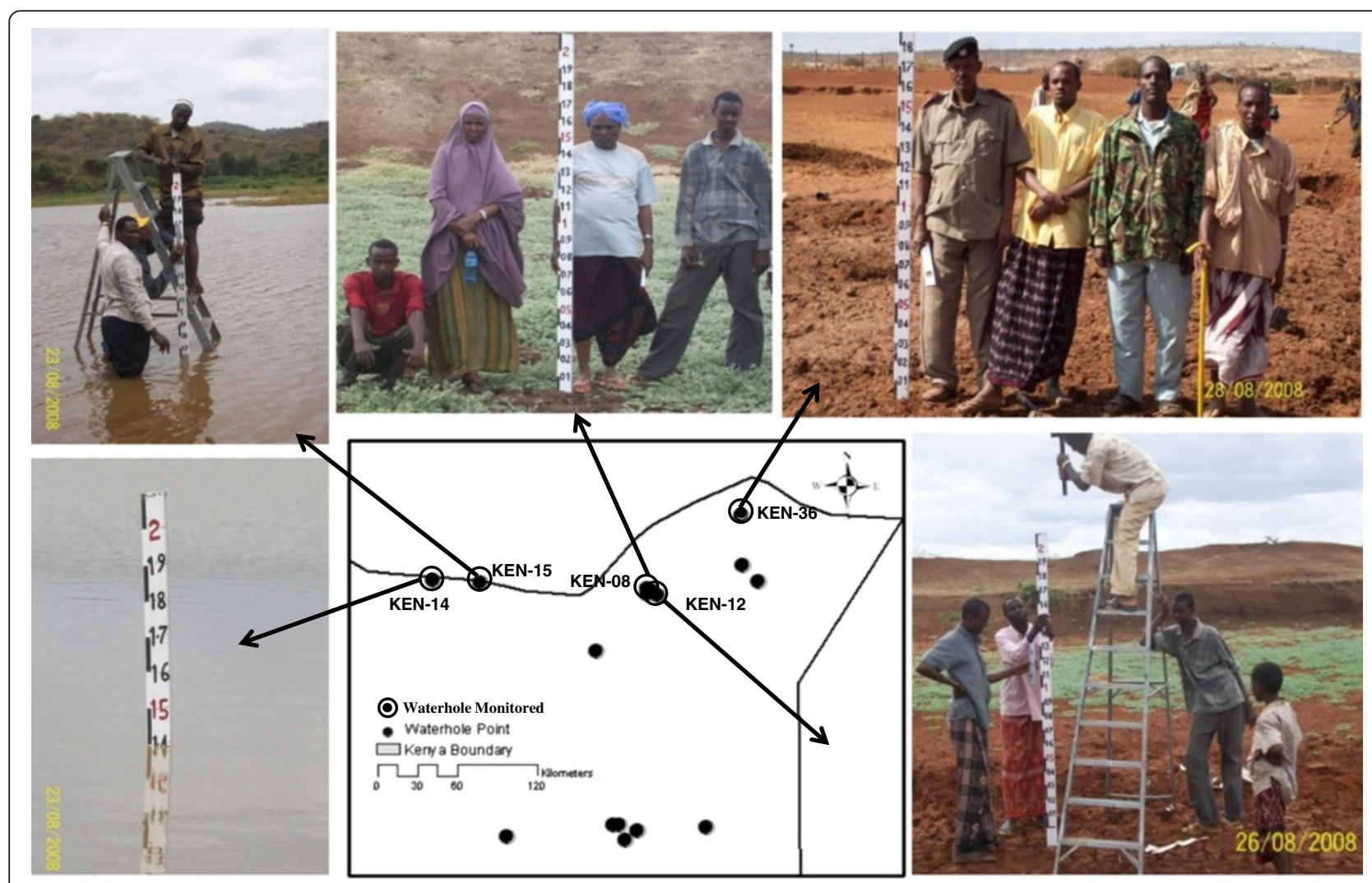

Figure 3 Installation of staff gauges in selected waterholes, used for collection of waterhole water level data for model validation. 
Table 3 Description of waterholes used for validation of modelled water levels

\begin{tabular}{|c|c|c|c|c|c|c|}
\hline \multirow[t]{2}{*}{ ID } & \multirow[t]{2}{*}{ Waterhole } & \multirow[t]{2}{*}{ Lattitude } & \multirow[t]{2}{*}{ Longgitude } & \multirow[t]{2}{*}{ Local name } & \multicolumn{2}{|c|}{ Data used for validation } \\
\hline & & & & & From & To \\
\hline 58 & KEN-14 & 38.7441 & 3.5079 & Dabala Fachana & Apr 2009 & July 2010 \\
\hline 59 & KEN-15 & 39.0640 & 3.4815 & Holale & Apr 2009 & July 2010 \\
\hline 82 & KEN-36 & 40.8705 & 3.9013 & Olla & Dec 2009 & Aug 2010 \\
\hline 23 & ETH-03 & 38.7509 & 3.7437 & Wirwita & Jan 2010 & Aug 2010 \\
\hline 45 & ETH-05 & 38.8434 & 3.6409 & Dembi Korba & Sept 2008 & Aug 2010 \\
\hline 5 & $\mathrm{ETH}-13$ & 38.2019 & 5.0018 & Beke & Sept 2008 & Aug 2010 \\
\hline 19 & ETH-26 & 38.4010 & 4.1402 & Dimtu & Jan 2010 & Aug 2010 \\
\hline 22 & ETH-29 & 38.4471 & 3.9814 & Jilo Dokicha & Jan 2010 & Aug 2010 \\
\hline
\end{tabular}

Field installed gauge data for the waterhole water levels used for validation.

installation activities in the Kenyan waterholes. Comparison and validation of modelled waterhole water levels were performed using the in situ data from three Kenyan and five Ethiopian waterholes. To compare the trends with the modelled scaled depths, in situ observations were converted to scaled depths using Equation 7. Data used for each waterhole for validation are shown in Table 3.

\section{Condition of the waterholes}

The main objective of this research is to provide information on the seasonal patterns and variations of the waterhole water levels so that NGOs, governmental organizations and other stakeholders can use the information for early warning and decision making. To facilitate easy understanding on the general condition of the waterholes in the region using expert knowledge, waterholes were classified into four categories based on their current condition as Good, Watch, Alert and Near-Dry (Table 4).

A waterhole is said to be in Good condition when the mean scaled depth over the previous 10 days is greater than the long-term median depth. A waterhole is in a Watch condition when the scale depth over the previous 10 days is between $50 \%$ and $100 \%$ of the long-term median depth. An Alert condition means that the scaled depth over the previous 10 days is between $3 \%$ and $50 \%$ of the long-term median depth. A waterhole is Near-Dry when the scaled depth over the previous 10 days is less than $3 \%$ of the median depth. A long-term median water level for each waterhole was computed using data from 1998 to 2011. Information on the waterhole condition is easy to understand and would enable pastoralists or other stakeholders to identify the general trend in water levels in the region and would aid in early warning and decision making for livestock movement and government intervention.

\section{Results and discussion}

\section{Characteristics of waterholes identified using ASTER imagery}

Figure 4 shows the spatial distribution of 90 waterholes identified from available ASTER imagery. Of those waterholes, 52 are in Ethiopia, 36 in Kenya and 2 in South Sudan. ASTER imagery covering only $85 \%$ of the study site was used in this analysis and clouded areas were masked out, which could mean that there are more waterholes in the region that were not identified. Of the 90 waterholes, 47 clear-water waterholes were identified using the SBR approach and 43 water-like waterholes were identified using the MAD approach. The size of the waterholes varied from less than a hectare (ETH-50) to 150 ha (ETH-40). The area of the catchments for these waterholes delineated using SRTM varied from 2 (ETH-46) to 28,900 ha (ETH-13) with a mean of 2,900 ha.

All the waterholes in Kenya and 30 waterholes in Ethiopia were visited. However, 2 waterholes in Sudan and 22 in Ethiopia were not visited due to inaccessibility and safety reasons. During the field campaigns, the locations of the waterholes identified from ASTER were verified using hand-held GPS units. Except for three waterholes in Kenya, the locations of all the waterholes were found to be accurate. Waterholes were also characterized for general hydrology, physical properties and usability. Eleven waterholes in Kenya were found to be recharged by groundwater systems. Water in six

Table 4 Classification of the condition of the waterholes

\begin{tabular}{|c|c|c|}
\hline No. & Class & Description \\
\hline 1 & Good & More than the long-term median water level \\
\hline 2 & Watch & $\begin{array}{l}\text { Between } 50 \% \text { and } 100 \% \text { of the long-term } \\
\text { median water level }\end{array}$ \\
\hline 3 & Alert & $\begin{array}{l}\text { Between } 3 \% \text { to } 50 \% \text { of the long-term } \\
\text { median water level }\end{array}$ \\
\hline 4 & Near-Dry & $<3 \%$ of the long-term median water level \\
\hline
\end{tabular}




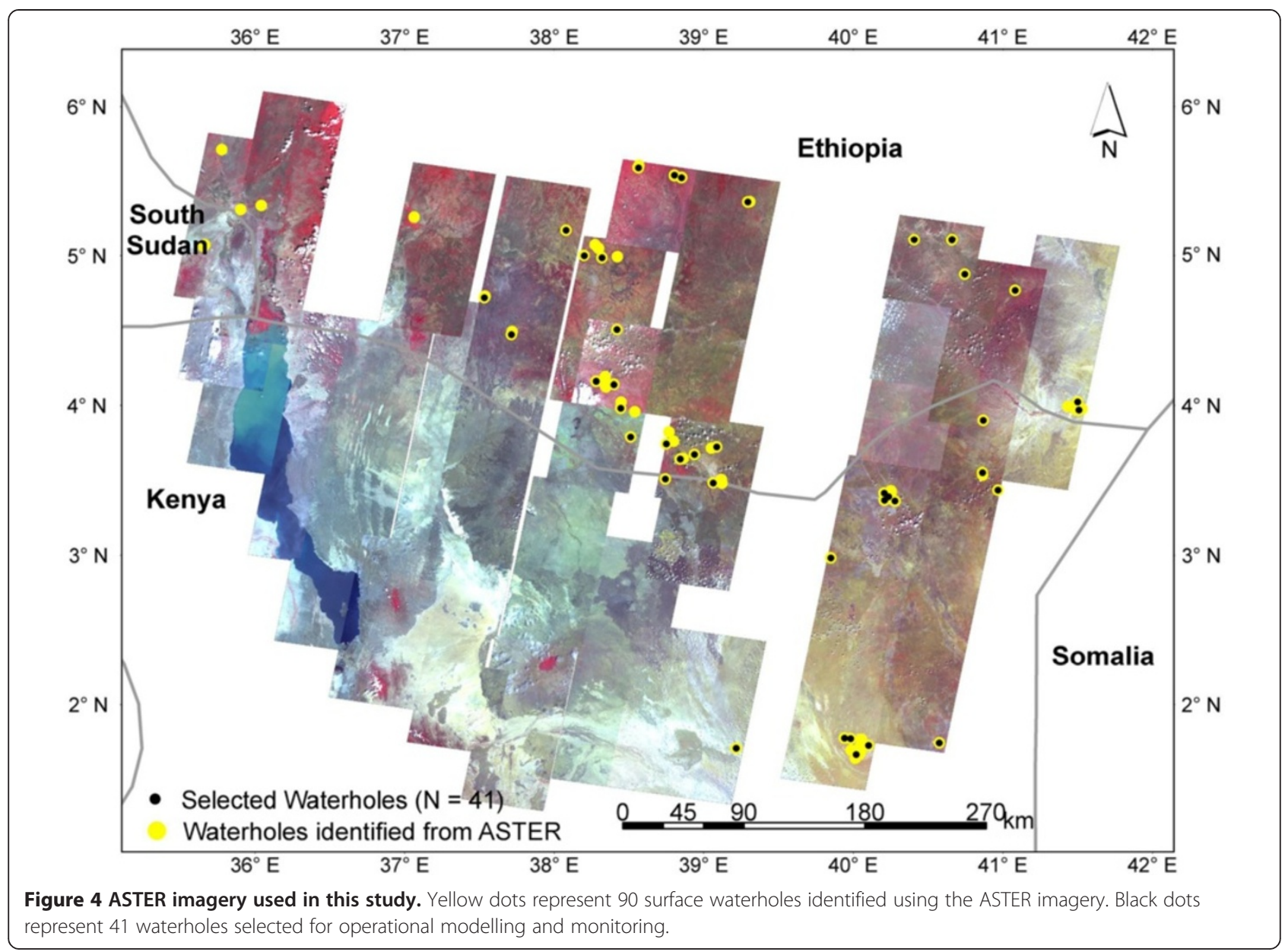

waterholes in Kenya was found to be saline and unusable by pastoralists. Thirteen waterholes in Kenya and 27 waterholes in Ethiopia were found to be in deteriorating condition with poor water quality. Information on other characteristics of waterholes such as the type of waterholes (natural ponds, pans, dams, earthen dams) and the usability of waterholes is listed in Table 5 . Based on the information gathered during the field campaign, the 41 waterholes identified as useful were chosen for modelling and monitoring.

\section{Modelling waterhole water levels}

Waterhole water levels were modelled using Equations 4 through 7 . The model was run daily on the selected set of 41 waterholes (black dots in Figure 4) from 1 January 1998 to the end of 2011. Figure 5 illustrates the dynamics of the waterhole water levels modelled in this study. A visual comparison of these waterholes indicates that much of the seasonal and climatic variations were captured by the model. It was observed that, due to uneven distribution of rainfall, $37 \%$ of the waterholes responded to the El Niño event that occurred in early 1998. All 41 (100\%) waterholes showed a decline in water levels during the 1999 to 2000 droughts, with water levels lying below the threshold during this time period. During the normal rainy season from 2004 to 2006, waterhole water levels

Table 5 Characteristics of waterholes identified using ASTER imagery

\begin{tabular}{llcc}
\hline No. & Waterhole characteristic & \multicolumn{2}{c}{ No. of waterholes } \\
\cline { 3 - 4 } & & Kenya & Ethiopia \\
\hline 1 & No. of waterholes visited & $36(100 \%)$ & $30(58 \%)$ \\
2 & Error in mapping waterholes & $3(9 \%)$ & $0(0 \%)$ \\
3 & Dams/earthen dams & $8(23 \%)$ & $20(67 \%)$ \\
4 & Ponds/pans & $26(76 \%)$ & $14(33 \%)$ \\
5 & Dry at time of visit & $14(41 \%)$ & $17(57 \%)$ \\
6 & Recharged from groundwater & $11(32 \%)$ & $0(0 \%)$ \\
7 & Saline & $6(18 \%)$ & $0(0 \%)$ \\
8 & Water for human + livestock use & $26(76 \%)$ & $29(97 \%)$ \\
9 & Waterhole used only by wildlife & $11(32 \%)$ & $1(3 \%)$ \\
10 & Deteriorating condition & $13(38 \%)$ & $27(90 \%)$ \\
\hline
\end{tabular}




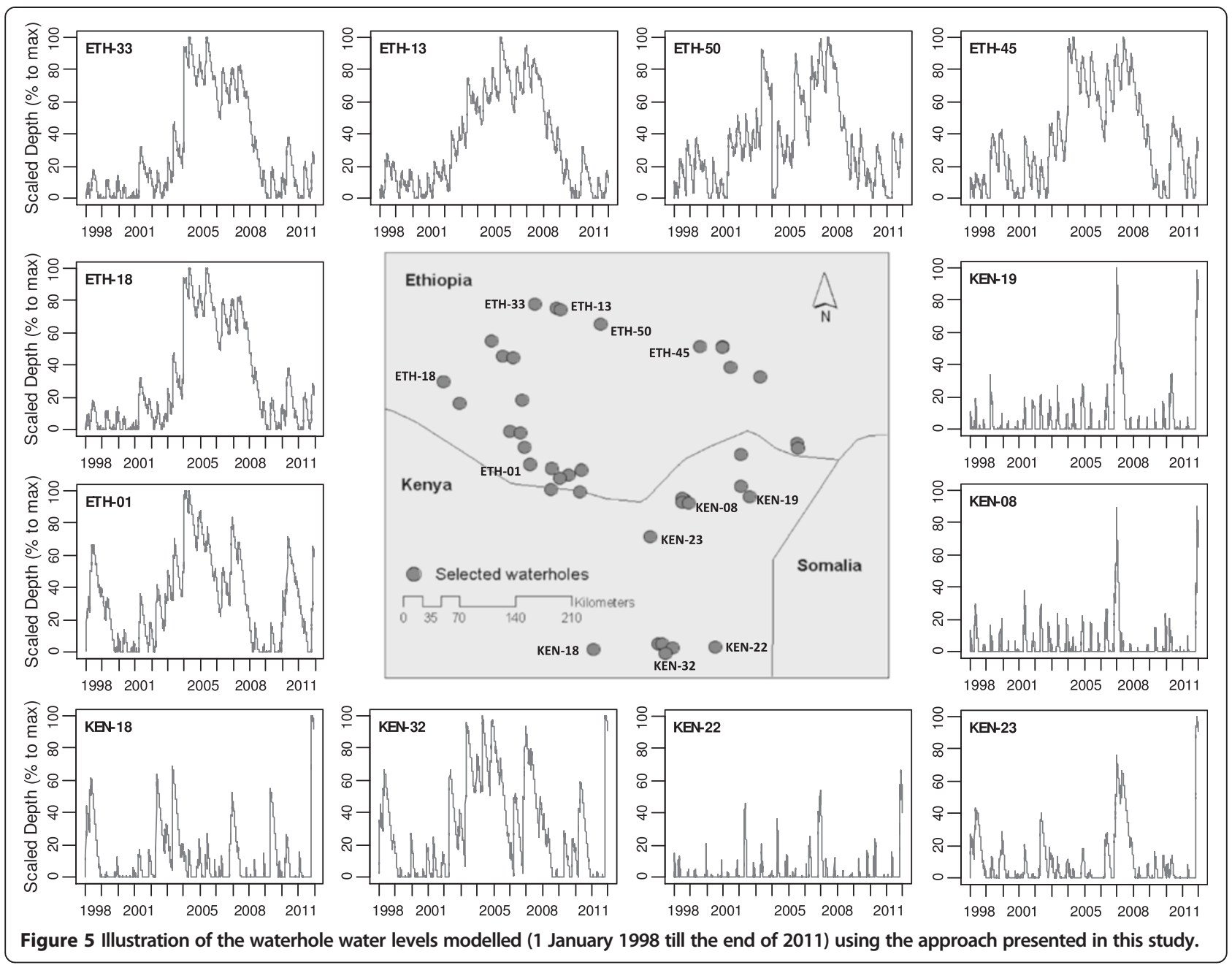

gradually improved, and $76 \%$ of the waterholes exceeded the upper threshold. In 36 (87\%) waterholes, water levels nearly reached maximum during the 2006 to 2007 El Niño. Finally, due to the failure of short rains during October to December 2009, water levels dropped in almost 40 (97\%) waterholes. Overall, the model reasonably captured the fluctuations and patterns caused by climatic variations.

An analysis of the response of seasonal and climatic variations on the waterholes was also investigated. Long-term daily mean water levels derived using 1998 to 2011 data were plotted to see the response of waterhole water levels to the seasonal fluctuations. Figure 6 shows the long-term daily mean water levels for $10 \mathrm{se-}$ lected waterholes. All the waterholes show an increase in water levels during April to May (beginning of the long rainy season). The water levels in most of the selected waterholes decreased during the summer season and increased during the short rainy season (October to December). This bimodal distribution of the waterhole water levels demonstrates that the model can capture seasonal variations. The lack of a smooth curve during the short rainy season also demonstrates the high year-to-year variability in the short rainy season in the region.

\section{Validation of scaled water levels with gauge data}

Validation results are shown in Figure 7. Validation results indicate that the modelled water levels reasonably match the field-installed gauge measurements in patterns and variations, with some differences in magnitude observed. To estimate model accuracy, simple Pearson's correlation coefficient and root-meansquared error (RMSE) were estimated for each of the eight validated waterholes. When compared to the in situ observations, correlation coefficients for the eight waterholes ranged from 0.18 to 0.8. RMSE values (on a scale of 0 to 1 ) were estimated and found to range from 0.1 to 0.28 with a mean RMSE of 0.22 . A major source of error was the difference in magnitude. However, the 


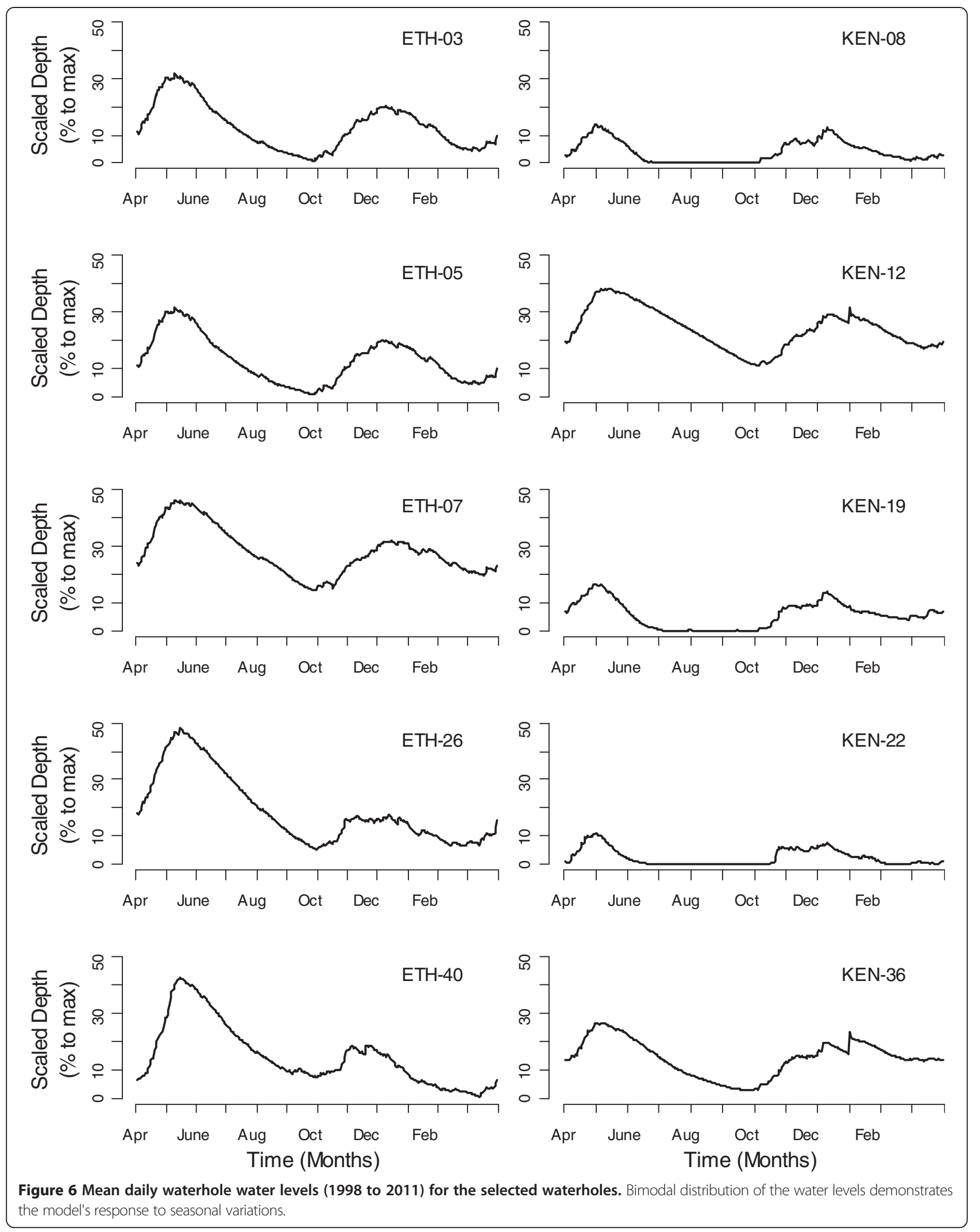




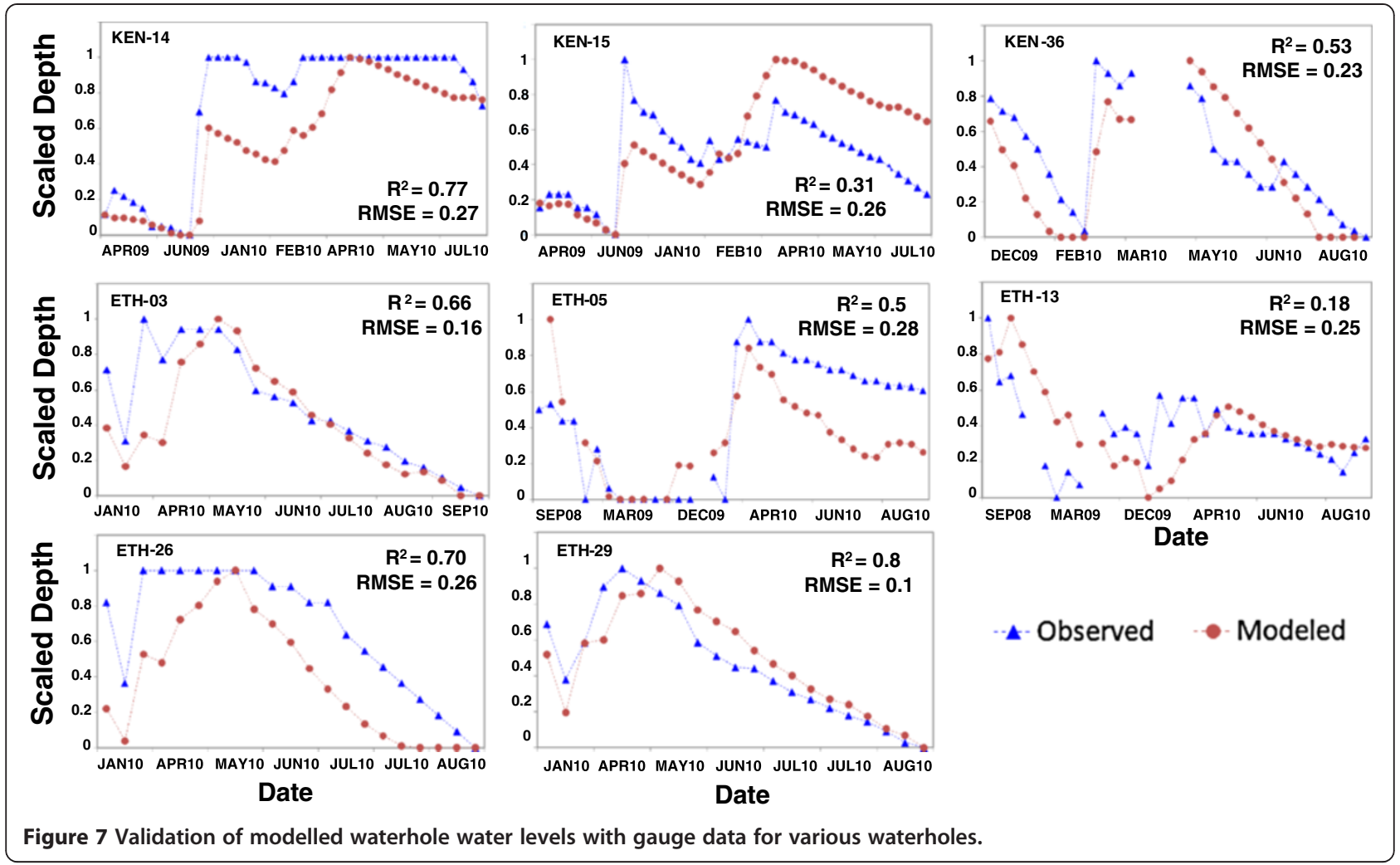

model was found to capture the general direction or trend in water level variations.

\section{Uncertainty in modelled scaled water levels}

In most hydrologic models using satellite data, major uncertainties in the model output can be attributed to the model parameters or input data. However, when data from various sources are combined as in the multisource water balance modelling approach driven by satellite data, it becomes extremely difficult to evaluate and eliminate all of the uncertainties associated with data and models. Major uncertainties in the modelling approach presented in this study could come from the rainfall, run-off and evapotranspiration estimates. Validation of TRMM rainfall over East Africa suggested that TRMM rainfall performed well with a bias less than $10 \%$ and RMSE of about 25\% (Dinku et al. 2008). Asadullah et al. (2008) indicated that satellite-based rainfall estimates in general can represent the main seasonal and spatial features of rainfall. However, TRMM data have spatial and temporal heterogeneity because of the method used to incorporate microwave estimates (Dinku et al. 2008), which could result in different accuracies across waterholes. Even though the relationship between rainfall and run-off is not linear from individual storms, considering the homogeneous land cover and the arid nature of the catchments, we assumed a constant rainfall-run-off coefficient of 0.05 to estimate run-off. However, the use of a constant run-off coefficient could introduce large errors in the modelled estimates over catchments with heterogeneous land cover and complex topography. Furthermore, globally available modelled evapotranspiration data sets show uncertainty of $15 \%$ to $30 \%$ (Kalma et al. 2008; Senay et al. 2008). The use of constant seepage could also contribute to errors.

Apart from the satellite data, other sources of errors such as measurement errors, substantial seepage losses from the waterholes and errors due to substantial water abstraction by livestock and humans could also result in additional errors. In spite of these sources of errors, the multi-source satellite data approach presented in this study can be used to monitor relative patterns and variations in water levels as opposed to absolute depths. This approach provides indicative information on relative water availability in near-real time, which otherwise is limited in the remote pastoral regions. Particularly, the use of scaled depths minimizes the negative impact of bias errors from input data and model parameterization. Due to the consistent nature of remote sensing data, the bias errors are largely eliminated from influencing the year-to-year variability of scaled depth, making it useful for drought monitoring and early warning applications. 


\section{Dissemination of information}

Data and information on the condition of the 41 selected waterholes in the pastoral regions of Ethiopia and Kenya are currently being disseminated through a dedicated website (http://watermon.tamu.edu). The value-added products on the current rainfall, evaporation, daily scaled depth and condition of the waterhole (Good, Watch, Alert and Near-Dry) can be obtained for each of the 41 waterholes in the region (Figures 8 and 9). Figure 8 is the snapshot of the water monitoring website (http://watermon.tamu.edu) showing the spatial distribution and the condition of the waterholes as of 23 February 2012. For each waterhole, users can also access and visualize data on rainfall, evaporation and scaled water level information from previous years since January 1998. Figure 9 illustrates that the scaled water level is well above the long-term median by the end of 2012 for the Ethiopian waterhole (Haro Korobissa). Figure 9 also shows online visualization and plotting options. The information is updated on the website in near-real time with a two-day delay due to the availability of input data sets required (rainfall and evapotranspiration data).

Use of information and communication technologies (ICT) for pastoral development

This study demonstrates the use of ICT for pastoral development. We demonstrated the use of satellite data that are readily available for download online for modelling relative water levels in the pastoral regions of northern Kenya and southern Ethiopia. In this study, we used mobile telephone technology to gather fieldinstalled gauge data from several local pastoral contacts. The data thus gathered by the national collaborating agencies were compiled and emailed to the researchers for validation. Furthermore, information on the condition of the waterholes is currently being disseminated through a dedicated web server in near-

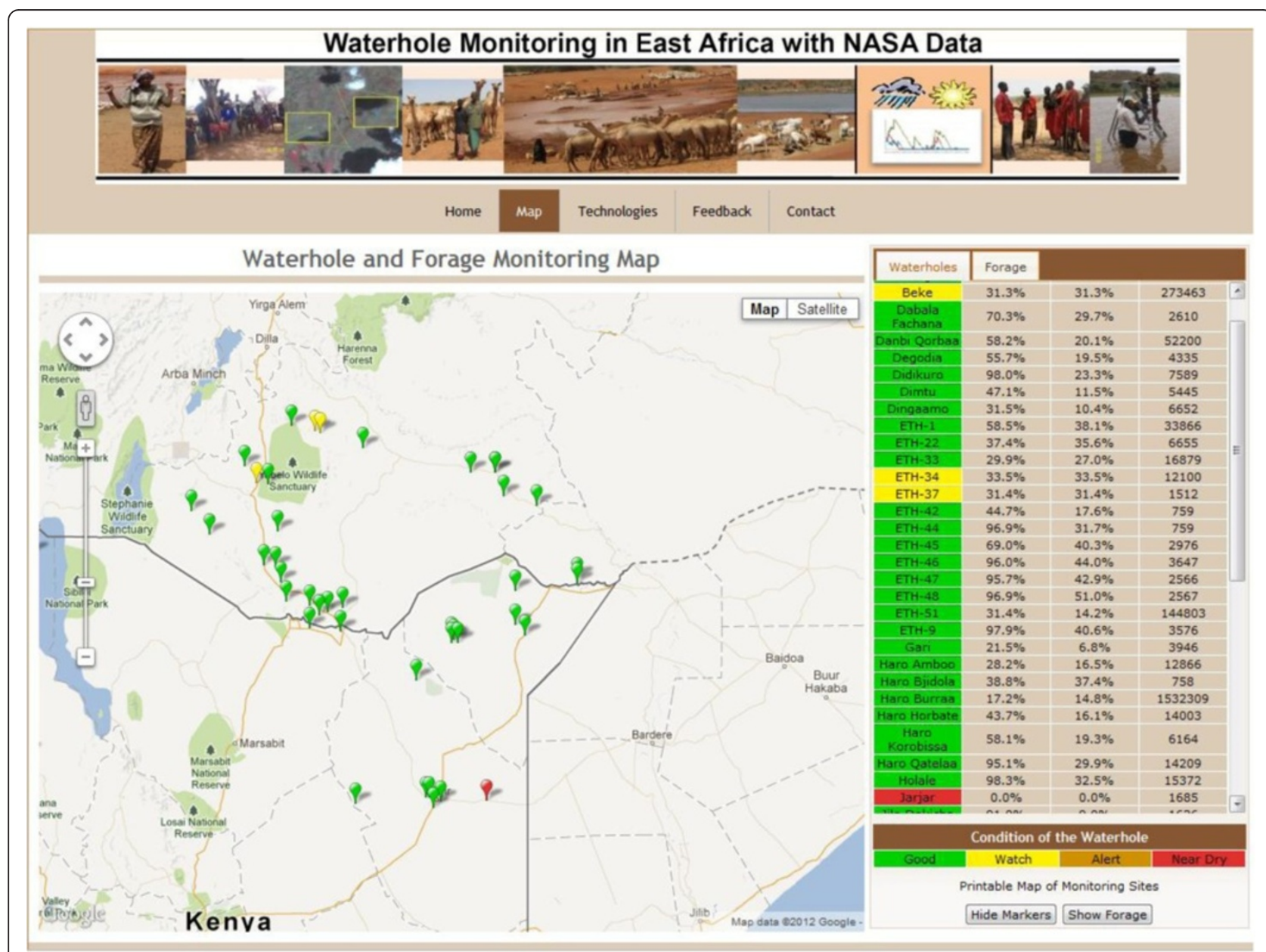

Figure 8 Condition of waterholes is denoted by colour of the balloons (as of 23 February 2012). Green means Good, yellow means Watch, brown means Alert and red means Near-Dry. The data are currently disseminated daily from http://watermon.tamu.edu/. 


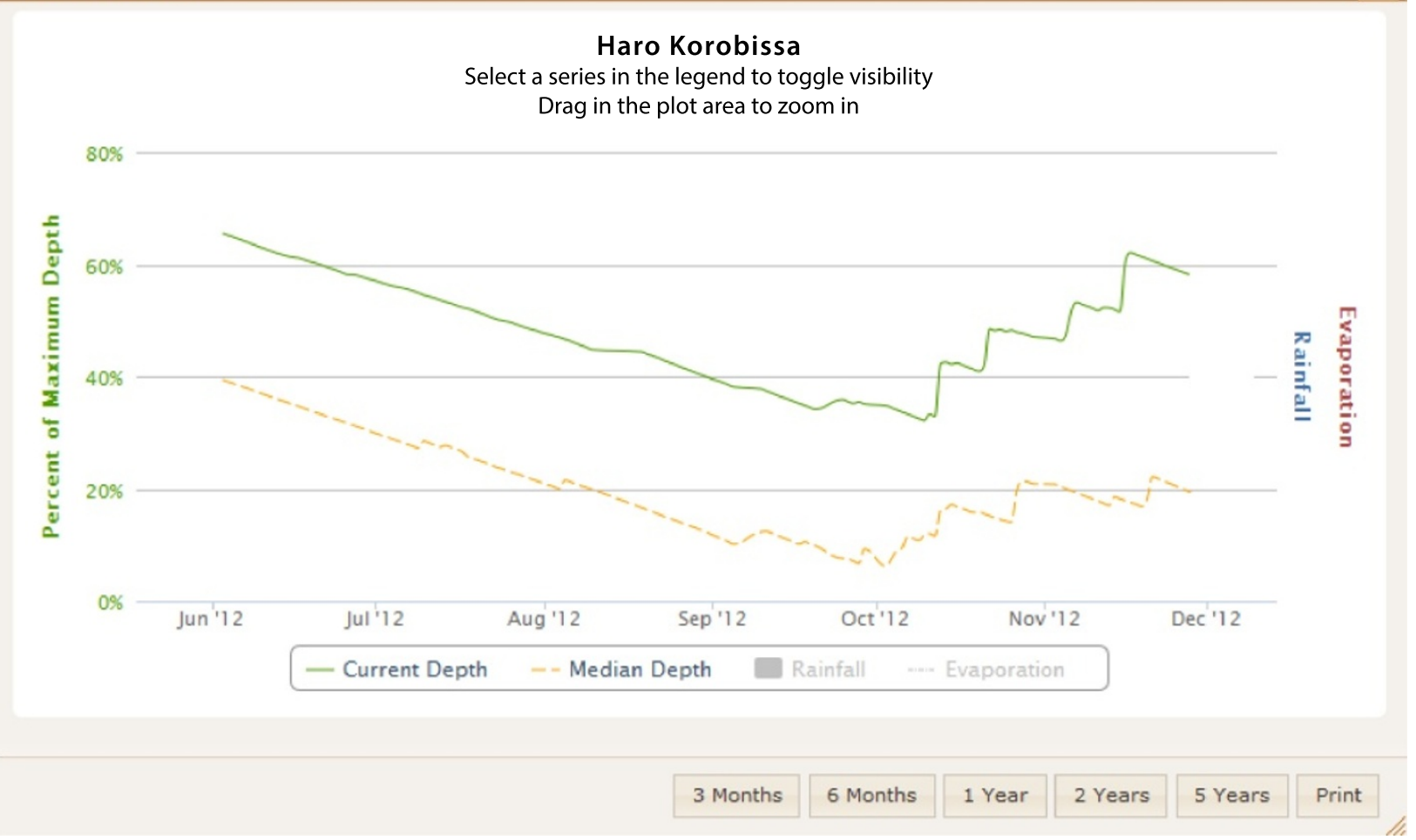

Figure 9 Current information on the scaled water levels for Haro Korobissa (ETH-30) as shown on http://watermon.tamu.edu. The green line indicates scaled depth and the dashed orange line indicates long-term median depth.

real time for local NGOs to download and disseminate to local stakeholders through the use of mobile phone technologies.

\section{Conclusions}

The main objective of this research was to provide useful early warning information on the seasonal patterns and variations of waterhole water levels located in the remote pastoral regions of East Africa. This study demonstrated the integration of high spatial resolution satellite data (30-m ASTER and 90-m SRTM DEM) with coarse, globally available, satellite-driven data sets (25-km TRMM and 100-km GDAS ETo) for operational modelling of waterhole water levels. Validation of modelled scaled depths with field-installed gauge data demonstrated the ability of the model to capture both the spatial patterns and seasonal variations. Modelled scaled estimates captured up to $60 \%$ of the observed gauge variability with an average RMSE of $22 \%$.

Up-to-date information and historical data (since 1998) on daily rainfall, evaporation, scaled depth and condition of each waterhole is currently being disseminated in nearreal time via the internet (http://watermon.tamu.edu).
Such information can help pastoralists, NGOs and other governmental organizations for early warning and decision making.

This study demonstrated an approach that uses multi-source satellite data to monitor seasonal patterns and variations in waterhole water levels in data-scarce pastoral regions of East Africa. The methodology presented in this study is being applied to monitor similar surface water bodies in other regions in Africa and has the potential to expand such monitoring in other parts of the world.

\section{Competing interests}

The authors declare that they have no competing interests.

\section{Authors' contributions}

GS: Responsible for concept development, design and implementation of this study; co-ordination of the field campaigns in Ethiopia and Kenya; responsible for drafting initial manuscript and subsequently involved in extensive revision of manuscript. NV: Processes satellite data and products used in this study. Developed codes for operational monitoring of the waterhole water levels; generated figures and tables; responsible for initial draft and revised manuscript. HA: Helped to process satellite data and products used in this study; Parameterization of water balance model. SP: Responsible for processing of ASTER imagery; identified waterholes from the ASTER imagery. KA: Responsible for the concept development, design and implementation of this study; helped in the initial design and co-ordination 
of the field campaign. GK: Responsible for liaison, collection and distribution of in-situ water level data in the Kenyan waterholes. TA: Responsible for liaison, collection and distribution of in-situ water level data in the Ethiopian waterholes. JA: Responsible for the design and co-ordination of the field campaigns. All authors read and approved the final manuscript.

\section{Acknowledgements}

This work was made possible by the funding of the Applied Science Program of NASA Earth-Sun System Division contract \# NNA06CH751 in collaboration with USGS FEWS NET (GR12D00BRHA100). We thank Robert Kaitho for his assistance in the field work. The authors are thankful to the Journal Editor and two anonymous reviewers for their constructive and helpful comments to improve the manuscript.

\section{Disclaimer}

Any use of trade, firm or product names is for descriptive purposes only and does not imply endorsement by the U.S. Government.

\section{Author details}

'U.S. Geological Survey (USGS) Earth Resources Observation and Science (EROS) Center, 252nd Street, Sioux Falls, SD 47914, USA. ${ }^{2}$ GISC Center of Excellence, South Dakota State University, 1021 Medary Avenue, Brookings, SD, USA. ${ }^{3}$ ASRC InuTeq LLC, Contractor for USGS EROS Center, 252nd Street, Sioux Falls, SD 47914, USA. ${ }^{4}$ Climatus LLC, 800 W El Camino \#180, Mountain View, CA, USA. International Livestock Research Institute, P.O. Box 30709, Nairobi 00100, Kenya. ${ }^{6}$ Oromia Agricultural Research Institute (OARI), Addis Ababa, Ethiopia. ${ }^{7}$ Ecosystems Science and Management, College of Agriculture and Life Sciences, Texas A\&M, Colleg Station, TX, USA.

\section{Received: 30 November 2012 Accepted: 8 July 2013}

Published: 4 September 2013

\section{References}

Allen, RG, LS Pereira, D Raes, and M Smith. 1998. Crop evapotranspiration: Guidelines for computing crop water requirements. FAO Irrigation and Drainage Paper. Rome: FAO. 56.

Anyamba, A, CJ Tucker, and JR Eastman. 2001. NDVI anomaly patterns over Africa during 1997/1998 ENSO warm event. International Journal of Remote Sensing 22: 1847-1859.

Asadullah, A, N McIntyre, and M Kigobe. 2008. Evaluation of five satellite products for estimation of rainfall over Uganda/Evaluation de cinq produits satellitaires pour l'estimation des précipitations en Ouganda. Hydrological Sciences Journal 53(6): 1137-1150.

Behera, SK, JJ Luo, S Masson, P Delecluse, S Gualdi, A Navarra, and T Yamagata. 2005. Paramount impact of the Indian Ocean dipole on the East African short rains: A CGCM study. Journal of Climate 18: 4514-4530.

Booth, DT, and PT Tueller. 2003. Rangeland monitoring using remote sensing. Arid Land Research and Management 17(4): 455-467.

Dinku, T, S Chidzambwa, P Ceccato, SJ Connor, and CF Ropelewski. 2008. Validation of high resolution satellite rainfall products over complex terrain. International Journal of Remote Sensing 29(14): 4097-4110.

Farr, TG, and M Kobrick. 2000. Shuttle Radar Topography Mission produces a wealth of data. EOS Transactions, AGU 81: 583-585.

Fratkin, E. 2001. East African pastoralism in transition: Maasai, Boran, and Rendille cases. African Studies Review 44(3): 1-25.

Galvin, KA, RB Boone, NM Smith, and SJ Lynna. 2001. Impacts of climate variability on East African pastoralists: Linking social science and remote sensing. Climate Research 19: 161-172.

Grigera, G, M Oesterheld, and F Pacin. 2007. Monitoring forage production for farmers' decision making. Agricultural Systems 94: 637-648.

Hagmann, T, and M Alemmaya. 2008. Pastoral conflicts and state-building in the Ethiopian lowlands. Afrika Spectrum 43(1): 19-37.

Harris, A, S Rahman, F Hossain, L Yarborogh, AC Bagtzoglou, and G Easson. 2007. Satellite based flood monitoring using TRMM-based rainfall products. Sensors 7: 3416-3427.

Hazarika, MK, TP Kafle, R Sharma, S Karki, RM Shrestha, and L Samarakoon. 2007. Statistical approach to discharge prediction for flood forecasts using TRMM data, Proceedings of the 5th annual Mekong flood forum. Ho Chi Minh City, Vietnam. May 17-18.

Huffman, GJ. 1997. Estimates of root-mean-square random error for finite samples of estimated precipitation. Journal of Applied Meteorology 36: 1191-1201.
Hundie, B. 2010. Conflicts between Afar pastoralists and their neighbors: Triggers and motivations. International Journal of Conflict and Violence 4(1): 134-148.

Hunt, ER, JH Everitt, JC Ritchie, MS Moran, DT Booth, GL Anderson, PE Clark, and MS Seyfried. 2003. Applications and research using remote sensing for rangeland management. Photogrammetric Engineering and Remote Sensing 69(6): 675-694.

IFRC. 2006. IFRC. 2006. Ethiopia: Floods. Operations update. International Federation of Red Cross and Red Crescent Societies. http://ifrc.org/docs/ appeals/06/MDRET00301.pdf. Accessed 29 Nov 2012.

Jama, A, R Kaitho, J Wu, and L Macopiyo. 2009. A new toolkit for monitoring and forecasting forage supply in the grazing lands of Eastern Africa. In The future of dry lands. International scientific conference on desertification and drylands research Tunis, Tunisia, ed. C Lee and T Schaaf, 349-358. Dordrecht: Springer.

Ji, Y. 2006. Validation of diurnal cycle and intra-seasonal variability of TRMM satellite rainfall. PIERS Online 2(6): 628-632.

Kalma, JD, TR McVicar, and MF McCabe. 2008. Estimating land surface evaporation: A review of methods using remotely sensed surface temperature data. Surveys in Geophysics 29(4): 421-469.

Meier, P, D Bond, and J Bond. 2007. Environmental influences on pastoral conflict in the Horn of Africa. Political Geography 26(6): 716-735.

Nicholson, SE, B Some, J Mccollum, E Nelkin, D Klotter, Y Berte, BM Diallo, I Gaye, G Kpabeba, O Ndiaye, JN Noukpozounkou, MM Tanu, A Thiam, AA Toure, and AK Traore. 2003a. Validation of TRMM and other rainfall estimates with a high-density gauge dataset for West Africa. Part I: Validation of GPCC rainfall product and pre-TRMM satellite and blended products. Journal of Applied Meteorology 42: 1337-1354.

Nicholson, SE, B Some, J Mccollum, E Nelkin, D Klotter, Y Berte, BM Diallo, I Gaye, G Kpabeba, O Ndiaye, JN Noukpozounkou, MM Tanu, A Thiam, AA Toure, and AK Traore. 2003b. Validation of TRMM and other rainfall estimates with a high-density gauge dataset for West Africa. Part II: Validation of TRMM rainfall products. Journal of Applied Meteorology 42: 1355-1367.

Rango, A, A Laliberte, JE Herrick, C Winters, K Havstad, C Steele, and D Browning. 2009. Unmanned aerial vehicle-based remote sensing for rangeland assessment, monitoring, and management. Journal of Applied Remote Sensing 3(1): 033542.

Reeves, MC, JC Winslow, and SW Running. 2002. Mapping weekly rangeland vegetation productivity using MODIS data. First virtual global conference on organic beef cattle production, September-October 2002.

Rowan, RC. 1995. PHYGROW model documentation version 2.0. Ranching Systems Group, Department of Rangeland Ecology and Management. College Station: Texas A\&M University.

Scoones, I, and O Graham. 1994. New directions for pastoral development in Africa. Development in Practice 4(3): 188-198.

SCS. 1972. National engineering handbook, Section 4, Hydrology. Washington, D.C.: SCS.

Senay, GB, and RL Elliott. 2002. Capability of AVHRR data in discriminating rangeland cover mixtures. International Journal of Remote Sensing 23(2): 299-312.

Senay, GB, and JP Verdin. 2004. Developing index maps of water-harvest potential in Africa. Applied Engineering in Agriculture 20(6): 789-799.

Senay, GB, JP Verdin, R Lietzow, and AM Melesse. 2008. Global daily reference evapotranspiration modeling and evaluation. Journal of American Water Resources Association 44: 969-979.

Sombroek, WG, HMH Braun, and BJA van der Pouw. 1982. Exploratory soil map and agro-climatic zone map of Kenya, 1980. Nairobi: Kenya Soil Survey Ministry of Agriculture - National Agricultural Laboratories.

Stuth, JW, J Angerer, R Kaitho, A Jama, and R Marambii. 2003. Livestock early warning system for Africa rangelands. In Agricultural drought monitoring strategies in the world, ed. V Boken. Oxford: Oxford University Press; 283-296.

Thoma, DP, DW Bailey, DS Long, GA Nielsen, MP Henry, MC Breneman, and C Montagne. 2002. Short-term monitoring of rangeland forage conditions with AVHRR imagery. Journal of Range Management 55(4): 383-389.

Tueller, PT. 1989. Remote sensing technology for rangeland management applications. Journal of Range Management 42(6): 442-453.

Velpuri, NM, GB Senay, and KO Asante. 2012. A multi-source satellite data approach for modelling Lake Turkana water level: Calibration and validation using satellite altimetry data. Hydrology and Earth System Science 16: 1-18.

Velpuri, NM, and GB Senay. 2012. Assessing the potential hydrologic impact of the Gibe III Dam on Lake Turkana water level using multi-source satellite data. Hydrology and Earth System Sciences 16(10): 3561-3578. 
World Food Program (WFP). 2000. Kenya's Drought: No sign of any let up. Rome, Italy: WFP. Available at: http://reliefweb.int/report/kenya/kenya-countryupdate-22-sep-2000-kenyas-drought-no-sign-any-let. Accessed 05 Aug 2013.

$X u, C Y$, and VP Singh. 2004. Review on regional water resources assessment under stationary and changing climate. Water Resources Management 18(6): 591-612.

doi:10.1186/2041-7136-3-20

Cite this article as: Senay et al:: Establishing an operational waterhole monitoring system using satellite data and hydrologic modelling: Application in the pastoral regions of East Africa. Pastoralism: Research, Policy and Practice 2013 3:20.

\section{Submit your manuscript to a SpringerOpen ${ }^{\circ}$} journal and benefit from:

- Convenient online submission

- Rigorous peer review

- Immediate publication on acceptance

- Open access: articles freely available online

- High visibility within the field

- Retaining the copyright to your article

Submit your next manuscript at $\boldsymbol{\wedge}$ springeropen.com 